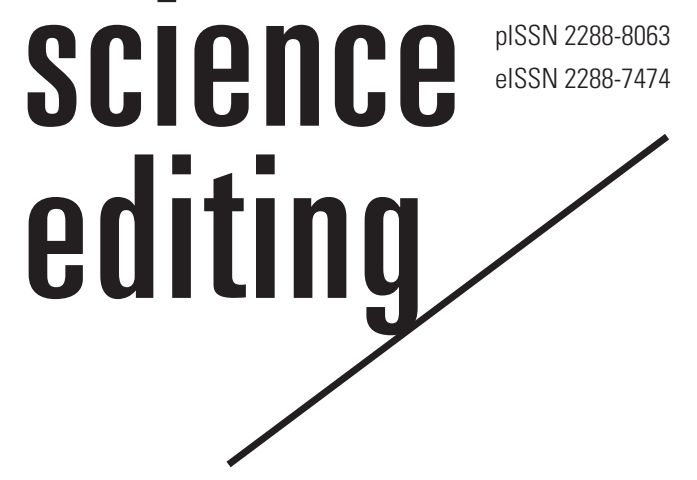

\title{
Establishment of the Indonesian Association of Scientific Journal Editors
}

\author{
Komang G. Wiryawan \\ Faculty of Animal Science, Bogor Agricultural University, Bogor, Indonesia
}

\section{Introduction}

A performance indicator for a country's research activity is the number of international publications in good quality and reputable international journals. Such publications in highly-reputable international journals are indicators of high-quality research and high-quality human resources in terms of science and technology innovation. One way to increase the number of publications in international journals is to promote target journals with high-quality articles. In order to be recognized as a good international journal, it should be registered in reputable international indexing organizations such as Scopus, Web of Science, PubMed, Directory of Open Access Journals (DOAJ), and EBSCO.

While Indonesia has more than 14,000 scientific journals [1], only a few journals are indexed in international databases. Up to 2019, Scopus indexes 49 Indonesian scientific journal titles [2], the Clarivate Analytics master journal list indexes 63, and DOAJ indexes 1,358. Those figures show that the majority of Indonesian scientific journals need improvement in order to be recognized as good quality international journals for acceptance by international indexes.

The Indonesian government has provided some support and policies to improve the quality of journals in the country. In the late 1990s, the Indonesian government introduced an accreditation system for national journals that aimed to improve journal management and quality. In the late 2000s, that measure was followed by the journals' internationalization policy for accredited publications [3]. The government provides grants for journal editors for the preparation of accreditation and internationalization, as well as workshops and assistance for both programs. Yet the sheer volume of journals in Indonesia means that the government is unable to assist them all. Therefore, the establishment of the Indonesian Association of Scientific Journal Editors (IASJE) is a necessary

Received: June 28, 2019 Accepted: July 15, 2019

Correspondence to Komang G. Wiryawan kgwiryawan@ipb.ac.id

ORCID

Komang G. Wiryawan https://orcid.org/0000-0002-0593-9653 step to support government programs aimed at improving journal quality in Indonesia.

\section{Overview of IASJE}

IASJE is a non-government, non-partisan, and non-profit organization. As its main objective is to improve the capacity of journal editors in Indonesia with regards to journal management and manuscript handling, the organization is consequently expected to improve journal quality. High-quality journals are expected to contribute to advances in science and technology, as well 
as human welfare as a whole.

IASJE was established on January 26, 2018 in Bogor, Indonesia during the First Indonesian Editors Congress (Figs. 1, 2). This event was attended by 50 journal editors from various institutions (universities; research and development of agriculture, ministry of agriculture; research and development of health, ministry of health; research and development of fisheries, ministry of marine affairs and fisheries; and delegation of the ministry of research, technology, and higher education). The congress was officially opened by the Vice Rector of Bogor Agricultural University, Bogor, Indonesia. The congress also discussed IASJE's statutes and by-laws, organizational structure, and programs.

\section{Vision, Mission, and Objectives}

IASJE's vision is to become an organization that contributes to the development and dissemination of science, technology, and arts in Indonesia. While its mission is to improve the quality and visibility of Indonesian scientific journals, as well as to disseminate and promote Indonesian journals at the international level.
IASJE's objectives are to improve the ability of journal editors in handling a journal; to improve the quality of Indonesian journals through sharing information with regards to manuscript handling and publication; to increase the visibility of Indonesian journals at the national, regional, and international levels; and to facilitate collaboration, communication, and information exchange with other organizations both at the national, regional, and international levels, and amongst IASJE members.

\section{Organizational Structure}

In order to accommodate IASJE's objectives, the organizational structure comprises an Advisory Board and Executive Board (Fig. 3). Advisory Board members have been selected to represent various institutions. The Executive Board consists of a president, secretary general, two vice-presidents, treasurer, and four committees. The first vice-president coordinates two of the committees (Education \& Training, Publication Ethics), while the second vice-president coordinates the other two (Publication \& Information, Collaboration). The president is

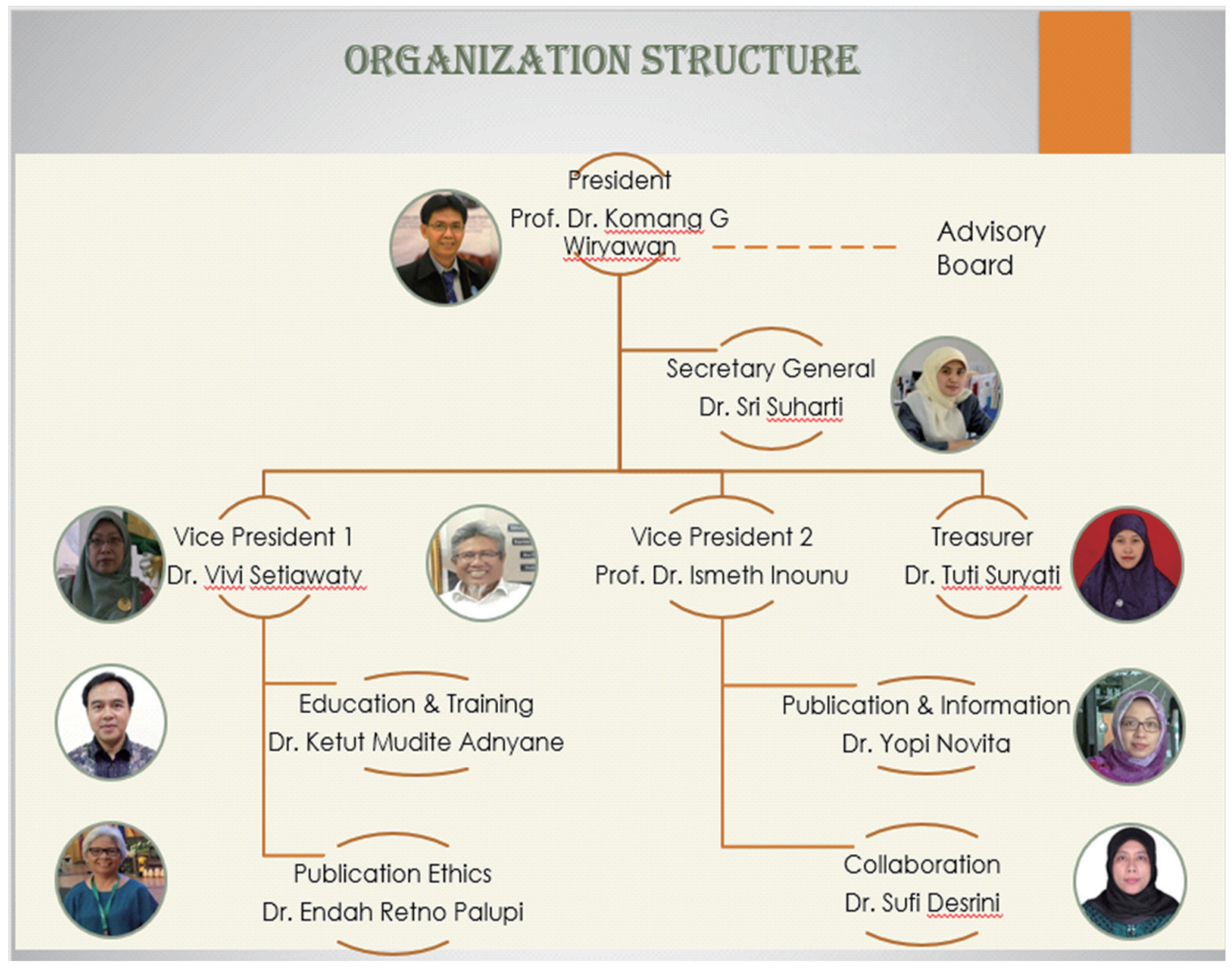

Fig. 1. Organizational structure of the Indonesian Association of Scientific Journal Editors. 

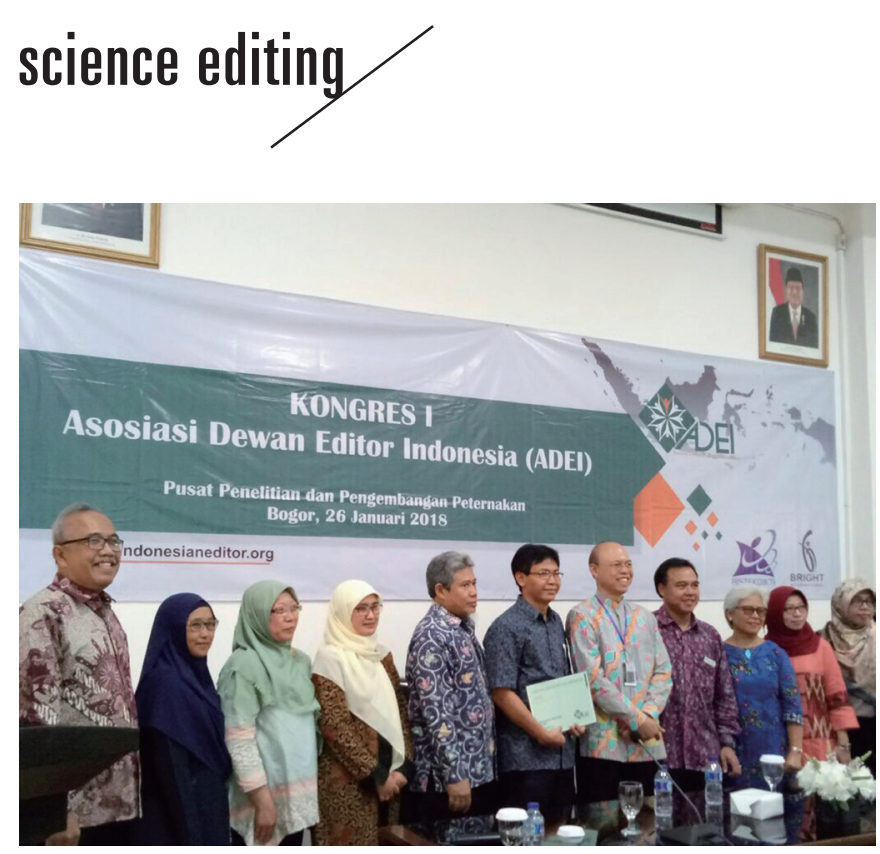

Fig. 2. Appointment of the president of the Indonesian Association of Scientific Journal Editors.

elected during the Congress for a 2-year term, and can be reelected for a second term. Executive board members come from various institutions such as universities, the ministry of agriculture, and the ministry of health. Each committee has five-to-ten members selected from different institutions.

\section{Programs}

Each committee has its own programs. The programs for Education \& Training are managing workshop/training activity related to manuscript review, manuscript editing, and the annual conference; providing standards and formats for manuscript editing; and establishing a certification system for journal editors.

The programs for Publication Ethics are planning and managing workshops on the standard of publication ethics in journal management; evaluating the practice of publication ethics; and resolving problems related to publication ethics misconduct by IASJE members.

Programs for Publication and Information are to organize the publication of a newsletter; to manage the IASJE website, and to disseminate all programs and activities of IASJE to all members.

Programs for Collaboration are to manage collaboration with scientific associations and academic institutions at the national, regional, and international levels; and to manage collaboration between IASJE members.

\section{Conclusion}

Establishing the IASJE is a challenging task. Effort is needed

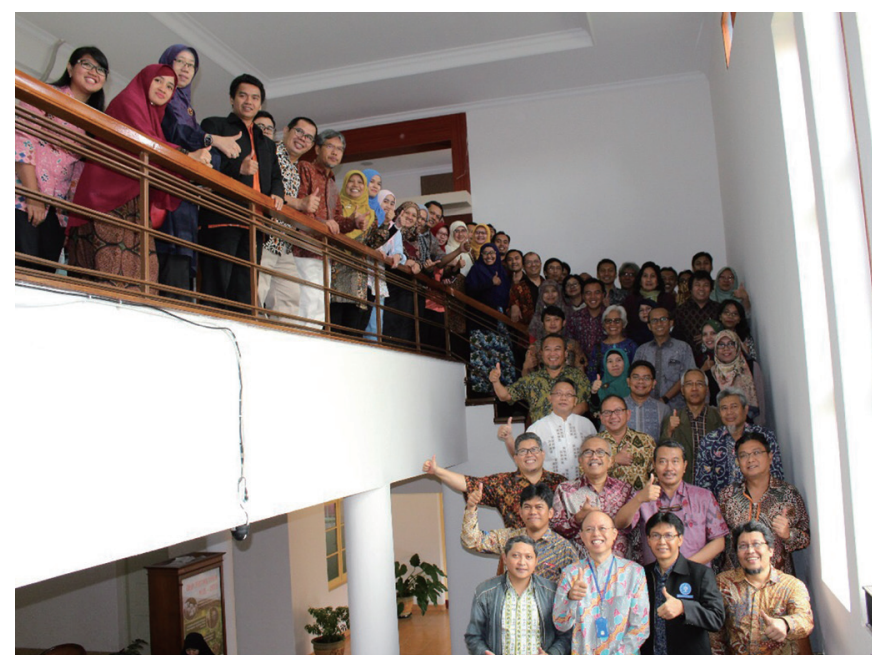

Fig. 3. Participants of the first indonesian editors congress for the establishment of the Indonesian Association of Scientific Journal Editors.

to persuade other journal editors and related institutions of the organization's benefits in terms of the development of scientific journals in Indonesia. Government support is also important, as IASJE's establishment mainly aims to support government programs in improving the quality of Indonesian journals. Strong cooperation between IASJE and the government over time will achieve a stronger impact and accelerate the improvement of journal quality in Indonesia.

\section{Conflict of Interest}

Komang G. Wiryawan serves as an editor of the Science Editing, but has no role in the decision to publish this article. Except for that, no potential conflict of interest relevant to this article has been reported.

\section{References}

1. Indonesian Scientific Journal Database. Directory of Indonesian scientific journals [Internet]. Jakarta: Centre for Scientific Documentation and Information [cited 2019 Jun 27]. Available from: http://isjd.pdii.lipi.go.id/index. php/public_no_login/index_direktori

2. Sinta. Journals in 2019 [Internet]. Jakarta: Ministry of Research, Technology, and Higher Education [cited 2019 Jun 27]. Available from: http://sinta2.ristekdikti.go.id/journals

3. Wiryawan KG. The current status of science journals in Indonesia. Sci Ed 2014;1:71-5. https://doi.org/10.6087/ kcse.2014.1.71 